\title{
Comparative Studies of the Phytoextraction Capacity of Five Aquatic Plants in Heavy Metal Contaminated Water
}

\author{
Erzsébet BUTA ${ }^{1}$, Anamária TÖRÖK² , Árpád CSOG² , Bilassé ZONGO³, \\ Maria CANTOR ${ }^{1}$, Mihai BUTA ${ }^{1}$, Cornelia MAJDIK ${ }^{2 *}$ \\ ${ }^{1}$ University of Agricultural Sciences and Veterinary Medicine, 3-5 Mănăştur Str., 400372, Cluj-Napoca, Romania \\ ${ }^{2}$ University of Babeş Bolyai, Faculty of Chemistry and Chemical Engineering, Arany János 11, Cluj-Napoca, Romania; \\ majdikc@yahoo.com (*correspondingauthor) \\ ${ }^{3}$ University of Ouagadougou, Laboratory of Biology and Ecology of Plants, 09 BP 848 Ouagadougou 09, Burkina Faso, Western Africa
}

\begin{abstract}
The uptake capacity of the aquatic plants (Salvinia natans Kunth., Eichbornia crassipes Mart., Lemna minor L., Elodea canadensis Michx., Pistia stratiotes L.) was analyzed in phytoextraction of $\mathrm{Cu}^{2+}, \mathrm{Zn}^{2+}$, and $\mathrm{Cd}^{2+}$. It was attend to study the plants capacity comparatively using mono and multimetallic systems. In particular, the chlorophyll, protein and carotenoids contents were studied during heavy metals uptake, in order to observe the stress effect on plants. The results obtained for the monometallic system showed that Salvinia natans Kunth. accumulated the highest quantity of $\mathrm{Cu}^{2+}(4.72 \mathrm{mg} / \mathrm{g}), \mathrm{Zn}^{2+}(2.23 \mathrm{mg} / \mathrm{g})$ and Cd $\mathrm{Cd}^{2+}(1.90 \mathrm{mg} / \mathrm{g})$. The leaves of Lemna minor L. accumulated the highest concentration of $\mathrm{Cu}^{2+}(10.80 \mathrm{mg} / \mathrm{g})$ and $\mathrm{Cd}^{2+}(2.78 \mathrm{mg} / \mathrm{g})$ in multimetallic system. The water lettuce (Pistia stratiotes $\mathrm{L}$.) translocated the highest quantity of $\mathrm{Zn}^{2+}$ in its roots ( $4.80 \mathrm{mg} / \mathrm{g}$ ). The chlorophyll and the carotenoids levels decreased under the stress of heavy metals in both systems, while protein content increased under the influence of $\mathrm{Cu}^{2+}$ and $\mathrm{Cd}^{2+}$, but decreased for $\mathrm{Zn}^{2+}$. The studied hydrophytes proved to be useful in the uptake of heavy metals in monometallic system and much more effective in the multimetallic system and showed great potential for further applications in the industrial and commercial wastewater treatments.
\end{abstract}

Keywords: hydrophytes, photosynthetic pigments, phytoaccumulation, pollution, proteins

Abbreviations: DW, drywt - dry weight; chl - chlorophyll; chl $a$ - chlorophyll $a$; chl $b$ - chlorophyll $b$; total chl - total chlorophyll; car - carotenoids; FW - fresh weight; DW - dry weight; HM - heavy metals; NPK - nitrogen, phosphorus, potassium.

\section{Introduction}

The environmental contamination with toxic elements is a major issue on a global scale. It can damage or alter the biosphere reducing the agricultural productivity and can affect both animal and human bodies (Buszewski et al., 2000; Cvjetko et al., 2010; Kamal et al., 2004; Kaur et al., 2010; Lu et al., 2004; Skinner et al., 2007).

The remediation of pollutants in different environmental conditions can be achieved through plants (phytoremediation), being considered an alternative technology to clean up contaminated waters. This method was also used in the $18^{\text {th }}$ century to treat wastewater, leading to extensive researches that allowed the study of metal phytoextraction processes. Moreover, the understanding of the physiological mechanisms of metal absorption, transportation and assimilation became possible (Mudgal et al., 2010).

Phytoremediation includes: phytoextraction, phytostabilization, rhizofiltration, phytodegradation and phytovolatilization. Through phytoextraction, plants remove the pollutants from a contaminated site (Maczulak, 2009). Hydrophytes can translocate and concentrate many kinds of contaminants including heavy metals, pesticides, explosives, oils (Hasan et al., 2007; Kamal et al., 2004) and nutrients (nitrate, ammonium, phosphate).

The hyperaccumulator plants can gather high concentrations of heavy metals (Kachenko et al., 2009) from contaminated sites, at a minimum percentage, which can vary depending on the pollutant involved (more than $1000 \mathrm{mg} / \mathrm{kg}$ of dry weight for copper, cobalt, nickel, chromium and lead; or more than $10,000 \mathrm{mg} / \mathrm{kg}$ for magnesium and zinc - Baker and Brooks, 1989). These plants are able to absorb heavy metals such as $\mathrm{Pb}, \mathrm{Hg}, \mathrm{Zn}$, $\mathrm{Co}, \mathrm{Cd}$, and $\mathrm{Cu}$ via roots, stems and leaves, and deposit them in their organism. Some of these elements are essential for the metabolic function for a large class of organisms, e.g. $\mathrm{Zn}, \mathrm{Fe}, \mathrm{Cu}, \mathrm{Cr}$ and $\mathrm{Co}$ (Hogan, 2010), while others are very toxic $(\mathrm{Cd}, \mathrm{Hg}, \mathrm{Pb})$.

In the case of a high heavy metal concentration, the uptake inhibition and transportation can take place for essential metals as well (Fe, $\mathrm{Zn}$ and $\mathrm{Mn}$ ), through 
antagonistic effects (Naaz and Pandey, 2010). Other authors analyzed the distribution, accumulation and selection of heavy metals on selective plants in the presence of chelating compounds (Csog et al., 2012; Mihucz et al., 2012).

The main source of these heavy metals usually find their path in the aquatic ecosystems, e.g. ponds, rivers and lakes (Kumar, 2010), and consist mostly of industrial residues, mining, military operations (Liang et al., 2009), fertilizers and pesticide applications, fuel production and urban wastes. Recently, the use of aquatic plants for treating wastewater has been reported as an economical device for the treatment of heavy metal pollution in contaminated wastewaters (Kumar, 2010). Several studies proved that the cost of phytoextraction is lower than other conventional engineering technologies. Phytoremediation is not just environmentally friendly, cost-effective and non-intrusive, but it also conserves the ecosystem efficiently (Kamal et al., 2004).

Many researches have been conducted regarding the ability of aquatics to remove heavy metals from contaminated waters. For a diversity of purposes, a number of studies have been made on several hydrophytes: Salvinia sp. (Dhir, 2009; Espinoza-Quinones et al., 2005), Potamogeton crispus (Aysel et al., 2010), Potamogeton pectinatus and Potamogeton malaianus (Peng et al., 2008). Recent studies highlight the effectiveness of Eichbornia crassipes (Hogan, 2010; Naaz and Pandey, 2010; Singh and Kalamdhad, 2013; Skinner et al., 2007), Typha angustifolia (Dilek and Aksoy, 2004), Myriophyllum heterophyllum (Aysel et al., 2010), Lemna minor (Alka and Tripathi, 2007; Rahman and Hasegawa, 2011; Yeşim et al., 2003) and Azolla caroliniana (Bennicelli et al., 2004). Some research studies demonstrate that Nymphaea varieties can accumulate heavy metals, consequently, they can be used as hyperaccumulators (Lavid et al., 2000).

The purpose of the present paper is to compare the phytoextraction capacity of five aquatic plants and monitor the accumulation and distribution of heavy metals into their morphological parts (leaves and roots). In order to evaluate the markers for stress responses in plants under heavy metal stress treatment, biochemical parameters such as chlorophyll, proteins and carotenoids were investigated.

\section{Materials and methods}

Plant material and growing conditions. During the experiment the following five hydrophytes were used: floating fern (Salvinia natans Kunth.), water hyacinth (Eichbornia crassipes Mart.), duckweed (Lemna minor L.), waterweed (Elodea canadensis Michx.) and water lettuce (Pistia stratiotes L.). The above mentioned species were grown in an educational greenhouse, for a period of 30 days at the University of Agricultural Sciences and Veterinary Medicine Cluj-Napoca, Romania. The plants were kept separately in 5 plastic tanks, filled with tap water, in addition of $0.5 \%$ Complex III (NPK) fertilizer.

After the growing period, the plants were used for $\mathrm{Cu}^{2+}$, $\mathrm{Zn}^{2+}$ and $\mathrm{Cd}^{2+}$ phytoremediation experiments. They were kept for acclimatization for a period of 3 days in modified Hoagland nutrient solution in laboratory conditions. The
Hoagland nutrient solution contained macro elements such as: $1.25 \mathrm{mM} \mathrm{KNO}_{3}$ (Potassium nitrate), $1.25 \mathrm{mM}$ $\mathrm{Ca}\left(\mathrm{NO}_{3}\right)_{2}$ (Calcium nitrate), $0.5 \mathrm{mM} \mathrm{MgSO}$ (Magnesium sulfate), $0.25 \mathrm{mM} \mathrm{KH}_{2} \mathrm{PO}_{4}$ (Monopotassium sulphate) and micronutrients such as: $10 \mu \mathrm{M}$ FeEDTA (Ethylenediaminetetraacetic acid) as iron source, $11.6 \mu \mathrm{M} \mathrm{H} \mathrm{H}_{3} \mathrm{BO}_{3}$ (Boric acid), $4.5 \mu \mathrm{M}$ $\mathrm{MnCl}_{2} 4 \mathrm{H}_{2} \mathrm{O}$ (Manganese chloride tetrahydrate), $0.19 \mu \mathrm{M}$ $\mathrm{ZnSO}_{4} 7 \mathrm{H}_{2} \mathrm{O}$ (Magnesium sulphate heptahydrate), $0.12 \mu \mathrm{M}$ $\mathrm{Na}_{2} \mathrm{MoO}_{4} 2 \mathrm{H}_{2} \mathrm{O}$ (Sodium molybdate), $0.08 \mu \mathrm{M} \mathrm{CuSO}_{4} 5 \mathrm{H}_{2} \mathrm{O}$ (Copper II sulphate pentahydrate). The dimension of the acquarium was $21 \mathrm{~cm} \times 38 \mathrm{~cm} \times 28 \mathrm{~cm}$. During the phytoremediation experiments the plants were exposed to electric light for 14 hours then to darkness for 10 hours at a temperature of $2428^{\circ} \mathrm{C}$.

The heavy metal stock solutions were made of salts such as $\mathrm{Cd}\left(\mathrm{NO}_{3}\right)_{2}$ (Cadmium nitrate), $\mathrm{ZnSO}_{4} \times 7 \mathrm{H}_{2} \mathrm{O}$ (Zinc sulphate heptahydrate) and $\mathrm{CuSO}_{4} \times 5 \mathrm{H}_{2} \mathrm{O}$ (Copper II sulphate pentahydrate). For accuracy purposes, the initial concentrations were analyzed by the Atomic Absorbance Spectrophotometer and the Inductively Coupled Plasma Mass Spectrometry. The concentrations of $\mathrm{Cu}^{2+}, \mathrm{Zn}^{2+}$ and $\mathrm{Cd}^{2+}$, used in all the aquatics studied, were of $10 \mathrm{mg} / \mathrm{L}$.

The heavy metal contamination was investigated in the monometallic and multimetallic system, but the control plants were left without heavy metal treatment. It is essential to specify that the monometallic system can be defined as a process of each plant's separate absorption of every heavy metal one-by-one. Moreover, the multimetallic system uses the treatment of the plants with the mixture of the mentioned heavy metals. In order to determine the phytoextraction capacity, the results of the treated plant samples were compared with the results of the untreated plant samples. The untreated and treated plant samples were dried at $70-80{ }^{\circ} \mathrm{C}$ for a period of 48 hours. After digestion with $\mathrm{HNO}_{3}$ (digestion of $1 \mathrm{~g}$ plant material with $10 \mathrm{ml}$ nitric acid $-69 \% \mathrm{HNO}_{3}$, left for 24 hours at $20{ }^{\circ} \mathrm{C}$ and for 8 hours at $100{ }^{\circ} \mathrm{C}$ ) the $\mathrm{Cu}^{2+}, \mathrm{Zn}^{2+}$ and $\mathrm{Cd}^{2+}$ concentrations were determined. Three replications were obtained of both systems.

In order to investigate the responses of the plants through the heavy metal treatments, the photosynthetic pigments (chlorophyll $a$-chl a; chlorophyll $b$-chl b, carotenoids-car) and the total content of protein were analyzed. The determination of chlorophyll in treated and untreated plant samples $(250 \mathrm{mg})$ was achieved through the extraction of photosynthetic pigments with $96 \%$ chilled ethanol being kept in the dark (for 12 hours). After a tenminute centrifugation, the supernatant absorbance (chl a $\mathrm{A}_{665}$, chl $b \mathrm{~A}_{649}$, car $\mathrm{A}_{470}$ ) was measured using the UV-Vis Spectrophotometer (GBC Cintra 202). The content of chl $a$, chl $b$ and total chl and car was determined by the method of Arnon (1949) using the formula suggested by Lichtenthaler and Wellburn (1983) and Lichtenthaler (1987). The protein content was estimated following the method of Bradford (1976) using serum albumin as a standard protein and it was measured in both mono and multimetallic solutions.

In order to establish quantitative differences between values, statistical analyses were performed using Microsoft Office Excel. The data results were expressed as standard deviation (SD) from three replicates for each sample, consequently Duncan's multiple range test was undertaken. 
175

\section{Results and discussion}

Based on the preliminary experiments and observations, the hydrophytes studied had a phytoremediation period of six days. In Romania, the permissible metal content in wastewaters in compliance with the law is: $0.1 \mathrm{mg} / \mathrm{dm}^{3}$ for $\mathrm{Cu}^{2+} ; 0.5 \mathrm{mg} / \mathrm{dm}^{3}$ for $\mathrm{Zn}^{2+}$ and $0.2 \mathrm{mg} / \mathrm{dm}^{3}$ for $\mathrm{Cd}^{2+}$ (http://www.epurare.euriteh.ro/legislatie/NTPA001\%202 8.02.2002.pdf). The phytoextraction capacity of the plants was determined by measuring the heavy metal concentrations before and after the experiments undertaken from the plant samples.

\section{Monometallic system}

The uptake of the plants studied and the bioaccumulation depend on the plant species and on the metal ion characteristics. Two hydrophytes $E$. crassipes Mart. and $P$. stratiotes L. were selected in order to analyze the heavy metal accumulation and distribution in the parts of the plant (root and leaves) and the obtained results are presented in Tab. 1. The controlled plant samples contain lower quantities of $\mathrm{Cu}^{2+}$ and $\mathrm{Zn}^{2+}$ ions (Tab. 1). The heavy metal distribution in the different morphological parts of the smaller plants studied was not investigated in monometallic condition.

Tab. 1. Accumulation and distribution of heavy metals $(\mathrm{mg} / \mathrm{g})$ in different parts of E. crassipes Mart. and P. stratiotes L., in monometallic system

\begin{tabular}{|c|c|c|c|c|c|}
\hline \multicolumn{6}{|c|}{ Monometallic system } \\
\hline \multirow[t]{2}{*}{ Species } & \multirow[t]{2}{*}{ Treatment } & \multicolumn{2}{|c|}{$\begin{array}{l}\text { Concentration } \\
(\mathrm{mg} / \mathrm{g})\end{array}$} & \multicolumn{2}{|c|}{$\begin{array}{l}\text { Accumulated concentration } \\
(\mathrm{mg} / \mathrm{g})\end{array}$} \\
\hline & & leaves & roots & leaves & roots \\
\hline \multirow{4}{*}{ E.crassipes Mart. } & $\mathrm{Cu}^{2+}$ & 0.005 & 0.003 & $0.36 \pm 0.02^{\mathrm{d}}$ & $1.46 \pm 0.3^{b}$ \\
\hline & $\mathrm{Zn}^{2+}$ & 0.075 & 0.041 & $0.32 \pm 0.03^{\mathrm{d}}$ & $0.81 \pm 0.07^{\circ}$ \\
\hline & $\mathrm{Cd}^{2+}$ & 0 & 0 & $0.13 \pm 0.01^{\mathrm{d}}$ & $1.72 \pm 0.2^{\mathrm{a}}$ \\
\hline & $\mathrm{Cu}^{2+}$ & 0.009 & 0.004 & $2.49 \pm 0.6^{a}$ & $1.33 \pm 0.2^{\mathrm{b}}$ \\
\hline \multirow[t]{2}{*}{ P.stratiotes $\mathrm{L}$. } & $\mathrm{Zn}^{2+}$ & 0.033 & 0.013 & $0.95 \pm 0.01^{\mathrm{b}}$ & $1.11 \pm 0.4^{b}$ \\
\hline & $\mathrm{Cd}^{2+}$ & 0 & 0 & $0.27 \pm 0.04^{c}$ & $1.42 \pm 0.3^{b}$ \\
\hline
\end{tabular}

$\overline{\text { Values represent } \pm \mathrm{SD}(\mathrm{n}=3)}$, small letters represent the statistical significant difference at $\mathrm{P}<0.05$.

The results obtained showed that the concentration of the three heavy metal ions was higher in the root and lower in the leaves. One exception was noticed in the case of $\mathrm{Cu}^{2+}$ treatment for $P$. stratiotes $\mathrm{L}$. which accumulated a higher concentration of $\mathrm{Cu}^{2+}$ ion $(2.49 \mathrm{mg} / \mathrm{g})$ in the leaves. These results demonstrate that $P$. stratiotes $\mathrm{L}$. is the most effective plant for the removal of this metal from aqueous solutions. In diversion of the E. crassipes Mart., $\mathrm{Cu}^{2+}$ accumulation was measured in a lower quantity in the leaves. As for the $\mathrm{Zn}^{2+}$ monometallic treatment the highest concentration was accumulated in $P$. stratiotes $\mathrm{L}$. roots $(1.11 \mathrm{mg} / \mathrm{g})$. This means that the phytoextraction period was not enough for the translocation of the $\mathrm{Zn}^{2+}$ ions from the root to the leaves. The results demonstrated that the highest $\mathrm{Cd}^{2+}$ ion accumulation was very significant in the case of E. crassipes Mart. in the plant roots $(1.72 \mathrm{mg} / \mathrm{g})$. In the case of $\mathrm{Zn}^{2+}$ ions, the $\mathrm{Cd}^{2+}$ heavy metal ions have been translocated only in lower concentrations in the leaves during the phytoremediation period. These results corresponded with Zhu et al. (1999) reports, regarding the phytoaccumulation and distribution process in the case of E. crassipes Mart.

The results concerning the accumulation of heavy metals in the entire plant of El. canadensis Michx., $S$. natans Kunth., L. minor L. are presented in the Tab. 2. The highest concentration of $\mathrm{Cu}^{2+}$ was registered in the leaves of $S$. natans Kunth. (4.71 mg/g), followed by $L$. minor L. (1.55 mg/g) with significant differences. Similar concentration in this element was removed by $E l$. canadensis Michx. (1.34 mg/g). The highest amount of $\mathrm{Zn}^{2+}$ and $\mathrm{Cd}^{2+}$ ions was accumulated in $S$. natans Kunth. leaves $(2.26$ and $1.90 \mathrm{mg} / \mathrm{g})$. The lowest concentration of $\mathrm{Zn}^{2+}(0.44 \mathrm{mg} / \mathrm{g})$ was registered in $L$. minor $\mathrm{L}$. The results showed that the greatest capacity to uptake and bind the heavy metals in monometallic systems was reached by $S$. natans Kunth. and $P$. stratiotes L. On the other hand, the ions distribution is representative only in the case of $\mathrm{Cu}^{2+}$ in the leaves of $P$. stratiotes L.

Tab. 2. The accumulated heavy metal concentration in leaves of different hydrophytes (El. canadensis Michx., L. minor L. and S. natans Kunth.), in monometallic system

\begin{tabular}{|c|c|c|c|}
\hline \multicolumn{4}{|c|}{ Monometallic system } \\
\hline Species & Treatment & $\begin{array}{l}\text { Concentration } \\
\text { in leaves } \\
(\mathrm{mg} / \mathrm{g})\end{array}$ & $\begin{array}{c}\text { Accumulated } \\
\text { concentration in } \\
\text { leaves } \\
(\mathrm{mg} / \mathrm{g})\end{array}$ \\
\hline \multirow{3}{*}{$\begin{array}{l}\text { El. canadensis } \\
\text { Michx. }\end{array}$} & $\mathrm{Cu}^{2+}$ & 0.044 & $1.34 \pm 0.1^{\mathrm{a}}$ \\
\hline & $\mathrm{Zn}^{2+}$ & 0.086 & $0.58 \pm 0.02^{b}$ \\
\hline & $\mathrm{Cd}^{2+}$ & 0 & $0.44 \pm 0.01^{b}$ \\
\hline \multirow{3}{*}{ L. minor L. } & $\mathrm{Cu}^{2+}$ & 0.003 & $1.55 \pm 0.6^{c}$ \\
\hline & $\mathrm{Zn}^{2+}$ & 0.044 & $0.44 \pm 0.01^{\mathrm{c}}$ \\
\hline & $\mathrm{Cd}^{2+}$ & 0 & $0.06 \pm 0.06^{\mathrm{NS}}$ \\
\hline \multirow{3}{*}{ S. natans Kunth. } & $\mathrm{Cu}^{2+}$ & 0.007 & $4.71 \pm 0.5^{\mathrm{a}}$ \\
\hline & $\mathrm{Zn}^{2+}$ & 0.003 & $2.23 \pm 0.6^{c}$ \\
\hline & $\mathrm{Cd}^{2+}$ & 0 & $1.90 \pm 0.2^{\mathrm{c}}$ \\
\hline
\end{tabular}
difference at $\mathrm{P}<0.05$.

\section{Multimetallic system}

An attempt was made to appraise the phytoextraction capacity of the plants, to present the competition between metals for a better understanding of metabolic pathways and to identify the phytoremediation mechanism of the plants.

Tab. 3 contains the results related to the accumulation and distribution of heavy metals in different morphological parts of $P$. stratiotes L. and E. crassipes Mart. The compared results showed that the presence of the three heavy metal ions has a major influence on the plants phytoextraction efficiency, and that the heavy metal bioaccumulation capacity has increased values. The heavy metal bioaccumulation of hydrophytes is not proportional in the plant body. A higher concentration of heavy metals was observed in the roots of the hydrophytes. An exception was noticed in the case of $P$. stratiotes L. where the highest quantity of $\mathrm{Cu}^{2+}$ ions was bioconcentrated in the leaves. The same effect was observed in the case of monometallic treatment. The highest quantity of $\mathrm{Cu}^{2+}$ was registered in the case of the $E$. crassipes Mart. The $\mathrm{Cu}^{2+}$ uptake of this plant increased; it was seven times higher in comparison 
with the monometallic system. The result obtained in the multimetallic experiment confirmed that $P$. stratiotes $\mathrm{L}$. has removed the highest concentrations of $\mathrm{Zn}^{2+}$ ions from the synthetic, water in a concentration of $8.07 \mathrm{mg} / \mathrm{g}$ plant biomass ( $4.89 \mathrm{mg} / \mathrm{g}$ in the root and $3.17 \mathrm{mg} / \mathrm{g}$ in leaves). The two hydrophytes $\mathrm{Cd}^{2+}$ ions uptake had increased. The highest removed quantity of cadmium can be noticed in $P$. stratiotes $\mathrm{L}$. The $\mathrm{Cd}^{2+}$ ions concentrations is three time higher than in the case of the monometallic treatment. Generally, the heavy metals are accumulated in the root and may be due to the process of rhizofiltration, which is commonly observed in aquatic plants (Vesely et al., 2011).

Tab. 3. Accumulation and distribution of heavy metals $(\mathrm{mg} / \mathrm{g})$ in different parts of E. crassipes Mart. and P. stratiotes L., in multimetallic solutions

\begin{tabular}{|c|c|c|c|c|c|}
\hline \multicolumn{6}{|c|}{ Multimetallic system } \\
\hline \multirow[t]{2}{*}{ Species } & \multirow[t]{2}{*}{ Treatment } & \multicolumn{2}{|c|}{$\begin{array}{c}\text { Concentration } \\
(\mathrm{mg} / \mathrm{g})\end{array}$} & \multicolumn{2}{|c|}{$\begin{array}{l}\text { Accumulated concentration } \\
(\mathrm{mg} / \mathrm{g})\end{array}$} \\
\hline & & leaves & roots & leaves & roots \\
\hline \multirow{3}{*}{ E.crassipes Mart. } & $\mathrm{Cu}^{2+}$ & 0.004 & 0.005 & $1.76 \pm 0.6^{c}$ & $5.84 \pm 0.4^{\mathrm{a}}$ \\
\hline & $\mathrm{Zn}^{2+}$ & 0.029 & 0.006 & $1.73 \pm 0.8^{c}$ & $3.03 \pm 0.2^{b}$ \\
\hline & $\mathrm{Cd}^{2+}$ & 0 & 0 & $0.39 \pm 0.3^{\mathrm{d}}$ & $3.58 \pm 0.5^{b}$ \\
\hline \multirow{3}{*}{ P.stratiotes L. } & $\mathrm{Cu}^{2+}$ & 0.003 & 0.007 & $3.64 \pm 0.06^{\mathrm{b}}$ & $2.98 \pm 0.7^{b}$ \\
\hline & $\mathrm{Zn}^{2+}$ & 0.013 & 0.047 & $3.17 \pm 0.3^{b}$ & $4.89 \pm 1.1^{\mathrm{a}}$ \\
\hline & $\mathrm{Cd}^{2+}$ & 0 & 0 & $0.88 \pm 0.02^{\mathrm{c}}$ & $3.29 \pm 0.4^{\mathrm{b}}$ \\
\hline
\end{tabular}
difference at $\mathrm{P}<0.05$

Results regarding the accumulation of HM (without distribution) in the smaller studied hydrophytes (El. canadensis Michx., L. minor L. and $S$. natans Kunth.) are presented in Tab. 4. The heavy metal uptake capacity was increased with the presence of three heavy metal ions in all the three aquatic plants. The highest $\mathrm{Cu}^{2+}$ ions bioaccumulation was measured in $L$. minor L. This plant $\mathrm{Cu}^{2+}$ ions uptake capacity has grown nine times more than in the monometallic system. Moreover, the obtained data showed that $L$. minor $\mathrm{L}$. was the most efficient also in the uptake of $\mathrm{Zn}^{2+}$ and $\mathrm{Cd}^{2+}$ ions from the multimetallic systems. El. canadensis Michx. proved to be a weak HM accumulator, in both the systems, even though it has been seen, that in the monometallic system this plant accumulates high amounts of $\mathrm{Cu}^{2+}(1.34 \mathrm{mg} / \mathrm{g})$, meanwhile registering low values of $\mathrm{Zn}^{2+}$ and $\mathrm{Cd}^{2+}$. In the multimetallic system, this species accumulated high amounts of $\mathrm{Cd}^{2+}$ (1.51 mg/g), but low $\mathrm{Cu}^{2+}$ and $\mathrm{Zn}^{2+}$ quantities. The $S$. natans Kunth. $\mathrm{Zn}^{2+}$ ions uptake has increased $(4.47 \mathrm{mg} / \mathrm{g})$ in the presence of the $\mathrm{Cu}^{2+}$ and $\mathrm{Cd}^{2+}$ ions. The obtained results suggested that the poisoned plant system needs more $\mathrm{Zn}^{2+}$ ions for protection. The $\mathrm{Zn}^{2+}$ ion is known to be involved in the chlorophyll biosynthesis. The all-presence of these metals usually raises the phytoextraction capacities, showing non-concurrence between the metals during absorption.

Plants Biochemical Response (chl and car content). Heavy metal pollution causes certain physiological and biochemical changes in the plants. The most significant biochemical changes can be observed in the photosynthethic pigment concentrations and in the total protein content (Dhir et al., 2008). Heavy metals stress can inhibit or stimulate the formation of new proteins in the plant samples. The photosynthetic pigments are considered as indicators of environmental stress (Liechtenthaler and Miehe, 1997) and their degradation can be observed as a response to HM toxicity (Bunea et al., 2012).

El. canadensis Michx. was selected to analyze the biochemical changes after the monometallic treatment. Fig. 1 contains the results of chl and car content from the treated plant samples. The results showed that after the $\mathrm{Zn}^{2+}$ monometallic exposure the plants were the most affected.

Tab. 4. The accumulated heavy metal concentration in leaves of El. canadensis Michx., L. minor L and $S$. natans Kunth., in multimetallic system

\begin{tabular}{|c|c|c|c|}
\hline \multicolumn{4}{|c|}{ Multimetallic system } \\
\hline Species & Treatment & $\begin{array}{c}\text { Concentration } \\
\text { in leaves } \\
(\mathrm{mg} / \mathrm{g})\end{array}$ & $\begin{array}{c}\text { Accumulated } \\
\text { concentration in } \\
\text { leaves } \\
(\mathrm{mg} / \mathrm{g})\end{array}$ \\
\hline \multirow{3}{*}{$\begin{array}{l}\text { El. canadensis } \\
\text { Michx. }\end{array}$} & $\mathrm{Cu}^{2+}$ & 0.036 & $0.48 \pm 0.01^{\mathrm{b}}$ \\
\hline & $\mathrm{Zn}^{2+}$ & 0.089 & $0.59 \pm 0.03^{\mathrm{b}}$ \\
\hline & $\mathrm{Cd}^{2+}$ & 0.003 & $1.51 \pm 0.2^{\mathrm{a}}$ \\
\hline \multirow{3}{*}{ L. minor L. } & $\mathrm{Cu}^{2+}$ & 0.003 & $10.81 \pm 1.3^{\mathrm{a}}$ \\
\hline & $\mathrm{Zn}^{2+}$ & 0.046 & $4.89 \pm 1.2^{\mathrm{b}}$ \\
\hline & $\mathrm{Cd}^{2+}$ & 0.000 & $2.78 \pm 0.9^{c}$ \\
\hline \multirow{3}{*}{ S. natans Kunth. } & $\mathrm{Cu}^{2+}$ & 0.006 & $3.56 \pm 0.1^{b}$ \\
\hline & $\mathrm{Zn}^{2+}$ & 0.002 & $4.47 \pm 0.3^{b}$ \\
\hline & $\mathrm{Cd}^{2+}$ & 0.000 & $1.09 \pm 0.4^{\mathrm{d}}$ \\
\hline
\end{tabular}
difference at $\mathrm{P}<0.05$.

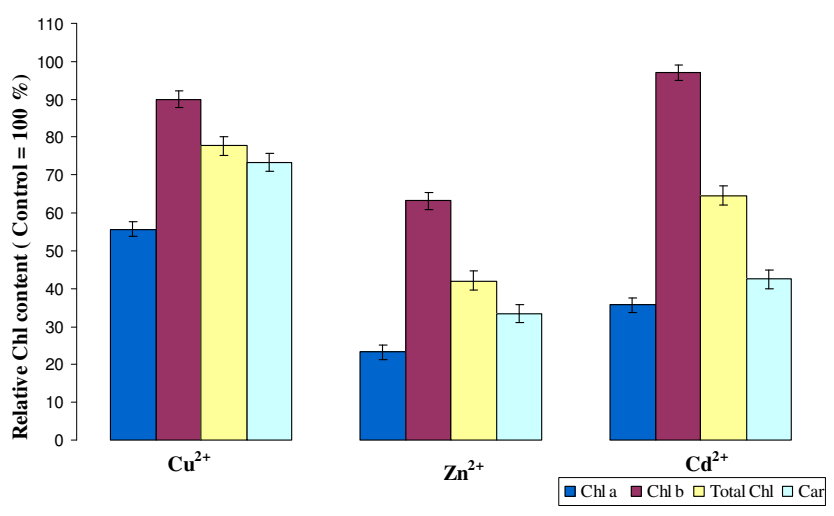

Fig. 1. The content of $\operatorname{chl} a, \operatorname{chl} b$, total chl and carotenoids of El. canadensis Michx. measured after the heavy metal treatment, in monometallic system

The multimetallic stress effects on the photosynthetic pigments content of the five studied aquatic plants are shown in Fig. 2 and 3. In this study, the chlorophyll concentrations decreased after six days of multimetallic exposure. A comparison of the relative sensitivity of the aquatic plants suggested that $S$. natans Kunth. is less sensitive to the three heavy metal ions than L. minor L., $P$. stratiotes L. and E. crassipes Mart. Hydrophytes showed the lowest chlorophyll content (Fig. 2) after the treatment. Moreover, the results confirmed that the three heavy metal ions had a major impact on the photosynthetic activity of the aquatic plants. 
177

The carotenoids content in this experiment have shown a decreasing tendency in all the studied species. The lowest concentration was registered in the case of El. canadensis Michx. followed by P. stratiotes L. (Fig. 3). The obtained results are in agreement with previous literature reports about the monometallic systems. Naumann et al. (2007) showed that $\mathrm{Cu}^{2+}$ may inhibit the chl and car biosynthesis in case of $L$. minor $\mathrm{L}$. The most sensitive parameters were observed on chl and car, followed by FW (fresh weight) and DW (dry weight). Hegazy et al. (2009) reported that chl and car content in $L$. gibba L. was altered by bioaccumulation of $\mathrm{Zn}^{2+}$ and $\mathrm{Cu}^{2+}$, therefore the plants have shown a significant discoloration of leaves. In the same time, with the growth of concentration of HM, the content of chl $a$ decreased, chl $b$ increased and the car became higher than total chl. Singh et al. (2012) reported that the effect of combined heavy metal treatment on toxicity symptoms of aquatic plants depends on the HM concentration and also, on the exposure time.
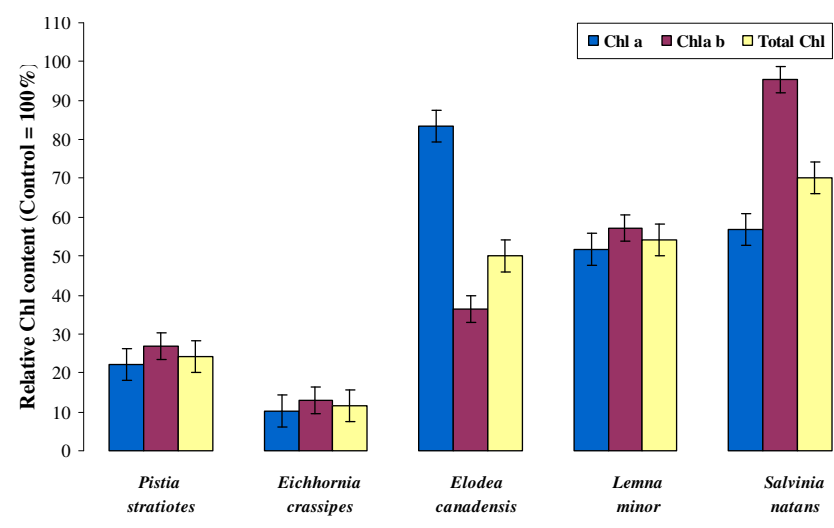

Fig. 2. The content of $\operatorname{chl} a, \operatorname{chl} b$, total chl of five aquatic plants measured after the multimetallic treatment

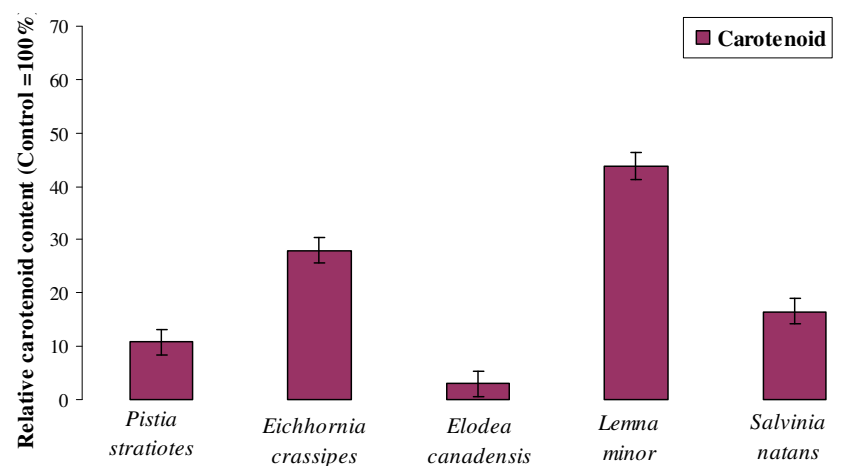

Fig. 3. The content of carotenoids of five aquatic plants measured after the multimetallic treatment

\section{Protein Content}

After the phytoremediation treatment with anorganic contaminants the plant metabolism is affected by lower or higher modifications in the protein content. The obtained results suggested that the correlation between removal rate and HM toxicity affected the protein content. The El. canadensis Michx. was selected for analysing the total protein content after the monometallic system. The results are presented in Fig. 4. Regarding these, the total protein content had increased after the $\mathrm{Cu}^{2+}$ and $\mathrm{Cd}^{2+}$ treatments. The total protein level decreased in the case of the $\mathrm{Zn}^{2+}$ exposure, which is in agreement with the report of Mishra and Tripathi (2008).

In the case of multimetallic systems the total protein content was measured in all five aquatic species. The results are shown in Fig. 5 in comparisons with the control plants content. The presence of the three toxic heavy metals in the aquatic environment has a main effect on the protein content in the case of P. stratiotes L., E. crassipes Mart. and El. canadensis Michx. The three mentioned aquatic plants protein concentration has increased after the multimetallic exposure. The plants possess a defence system, therefore the increased amount of protein could indicate the induction of stress proteins.

In the studied species with smaller morphological parts such as $L$. minor L. and S. natans Kunth., protein content has decreased after the heavy metal treatments. These results are in agreement with Singh's et al. (2012) reports concerning the decrease of total protein content in multimetallic system, which can generate higher toxicity effects on plant protein concentration.

The consequence of this study showed that the protein level in different aquatic species is in accordance with the HM accumulation. Phytoextraction results showed that the increasing protein content is involved in HM stress

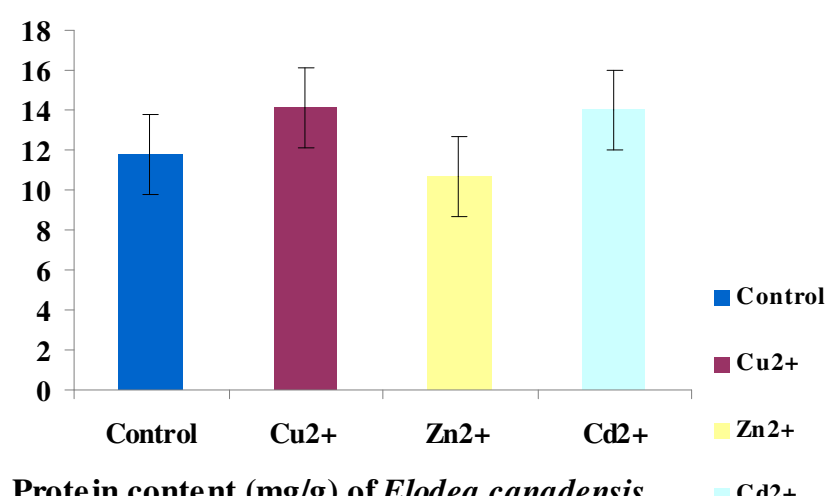

Fig. 4. The protein content of El. canadensis Michx. measured after the heavy metal treatment, in monometallic system (mg/g).

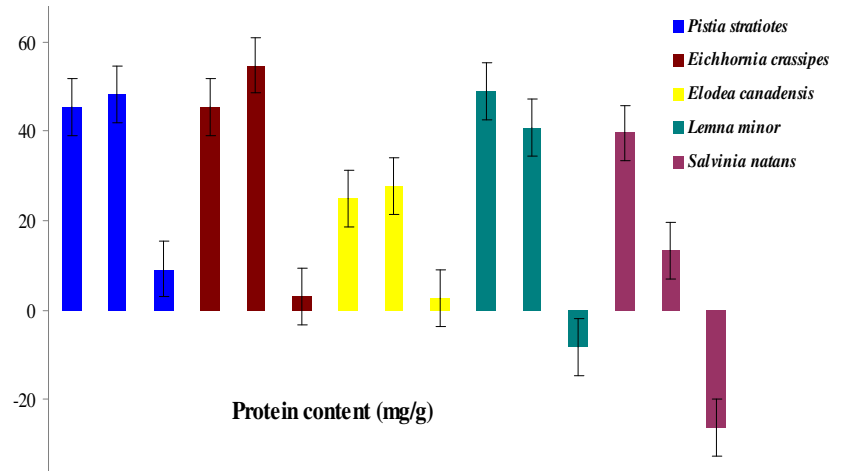

$-40-$

Fig. 5. Total protein content in control plants $(\mathrm{mg} / \mathrm{g})$, in treated plants and differences compared with control (untreated plants) and the studied species 
response. It was also observed, that in case of El. canadensis Michx. the mixture of the three metal ions did not disturb the accumulation mechanism and the level of total proteins was higher than in the monometallic treatment.

\section{Conclusions}

The studied macrophytes proved to be useful in the uptake of heavy metals in monometallic system and much more effective in multimetallic system. The plant uptake and accumulation of toxic $\mathrm{Cd}^{2+}$ ions have been advantageously influenced by the presence of $\mathrm{Cu}^{2+}$ and $\mathrm{Zn}^{2+}$ ions. The responses of plants to heavy metal stress can vary depending on: the decrease in chl and car content, the inhibition and induction of soluble protein quantity. In the case of protein content two kinds of reactions were suggested: 1. the reduction of protein level as an effect of the metal ions toxicity, 2. the increase, from the production point of view, of new protein synthesis. The measurements of photosynthetic pigment concentration, revealed the highest heavy metal tolerance in the $L$. minor L. and $S$. natans Kunth species.

\section{Acknowledgements}

This study was financially supported by the University of Agricultural Sciences and Veterinary Medicine ClujNapoca, Romania, Grant No. 1215/18/2012 (Director: Lecturer Erzsebet BUTA, PhD).

\section{References}

Alka RU, Tripathi BD (2007). Principle and process of biofiltration of $\mathrm{CD}, \mathrm{Cr}, \mathrm{Co}, \mathrm{Ni}$ and $\mathrm{Pb}$ from tropical opencast colamine effluent. Water Air Soil Pollut 180:213-223.

Arnon DI (1949). Cooper enzyme in isolated chloroplast polyphenol oxidase in Beta vulgaris. Plant Physiol 24:1-15.

Aysel S, Elmas E, Gümüş F, Ridvan ES (2010). Removal of cadmium by Myriophyllum heterophyllum Michx. and Potamogeton crispus L. and its effect on pigments and total phenolic compounds. Arch Environ Contam Toxicol 54:612618.

Baker AJM, Brooks RR (1989). Terrestrial higher plants which hyperaccumulate metallic elements - A review of their distribution, ecology and phytochemistry. Biorecovery 181126.

Bennicelli R, Pniewska ZSt, Banach A, Szajnocha K, Ostrowski J (2004). The ability of Azolla caroliniana to remove heavy metals (Hg (II), Cr (III), Cr (VI)) from municipal waste water. Chemosphere 55:141-146.

Bradford M (1976). A rapid and sensitive method for the quantitation of microgram quantities of protein utilizing the principle of protein-dye binding. Anal Biochem 72:248-254.

Bunea CI, Pop N, Babes AC, Matea C, Dulf FV, Bunea A (2012). Carotenoids, total polyphenols and antioxidant activity of grapes (Vitis vinifera) cultivated in organic and conventional system. Chem Cent J 6:1-9.

Buszewski BA, Jastrzębsk A, Kowalkowski T, Górna-Binkul A (2000). Monitoring of selected heavy metals uptake by plants and soils in the area of Torun, Poland. Pol J Environ Stud 9:511-515.

Csog A, Mihucz VG, Tatar E, Fodor F, Virag I, Majdik C, Zaray Gy (2011). Accumulation and distribution of iron, cadmium, lead and nickel in cucumber plants grown in hydroponics containing two different chelated iron supplies. J Plant Physiol 168:1038-1044.

Cvjetko P, Tolić S, Šikić S, Balen B, Tkalec M, Vidaković-Cifrek $\check{Z}$, Pavlica M (2010). Effect of copper on the toxicity and genotoxiticity of cadmium in duckweed (Lemna minor L.). Arh Hig Rada Toksikol 61:287-295.

Dhir B, Sharmila P, Saradhi PP (2008). Photosynthetic performance of Salvinia natans exposed to chromium and zinc rich wastewater. Braz J Plant Physiol 20:61-70.

Dhir B (2009). Salvinia: an aquatic fern with potential use in phytoremediation. Environ We Int J Sci Tech 4:23-27.

Dilek DR, Aksoy A (2004). Accumulation of heavy metals in Typha angustifolia (L.) and Potamogeton pectinatus (L.) living in Sultan Marsh (Kayseri, Turkey). Chemosphere 56:685-696.

Espinoza-Quinones FR, Zacarkim CE, Palacio SM, Obreg' on CL, Zenatti DC, Galante RM, Rossi N, Rossi FL, Pereira IRA, Welter RA (2005). Removal of heavy metal from polluted river water using aquatic macrophytes Salvinia sp. Braz J Phys 35:744-746.

Hasan SH, Talat M, Rai S (2007). Sorption of cadmium and zinc from aqueous solution by water hyacinth (Eichhornia crassipes). Bioresources Technol 98:918-928.

Hegazy AK, Kabiel HF, Fawzy M (2009). Duckweed as heavy metal accumulator and pollution indicator in industrial wastewater ponds. Desalin Water Treat 12:400-406.

Hogan CM (2010). Heavy metal. Encyclopedia of Earth. National Council for Science and the Environment. Eds E. Monosson \& C. Cleveland, Washington DC, Retrieved from http://www.eoearth.org/view/article/153463.

Kachenko GA, Bhatia PN, Siegele R, Walsh KB, Singh B (2009). Nickel, $\mathrm{Zn}$ and $\mathrm{Cd}$ localization in seeds of metal hyperaccumulators using $\mu$-PIXE spectroscopy. Nucl Instrum Meth B 267:2176-2180.

Kamal M, Ghaly AE, and Mahmoud N, Cote R (2004). Phytoaccumulation of heavy metals by aquatic plants. Environ Int 29:1029-1039.

Kaur L, Kasturi G, Sharma S (2010). Effect of pH and lead concentration on phytoremoval of lead from lead contaminated water by Lemna minor. Am-Euras J Agric and Environ Sci 7:542-550.

Kumar RP (2010). Phytoremediation of heavy metals in a tropical impoundment of industrial region. Environ Monit Assess 165:529-537.

Lavid N, Barkay Z, Tel-Or E (2000). Accumulation of heavy metals in epidermal glands of the waterlily (Nymphaeceae). 
179

Plant J 212:313-322.

Liang HM, Lin TH, Chiou JM, Yeh KC (2009). Model evaluation of the phytoextraction potential of heavy metal hyperaccumulators and non - hyperaccumulators. Environ Pollut 157:1945-1952.

Lichtenthaler HK, Wellburn AR (1983). Determination of total carotenoids and chlorophylls $\mathrm{a}$ and $\mathrm{b}$ of leaf in different solvents. Biochem Soc Trans 11:591-592.

Lichtenthaler HK (1987). Chlorophylls and carotenoids: Pigments of photosynthetic biomembranes. Meth Enzymol 148:350-382.

Liechtenthaler HK, Miehe JA (1997). Flourescence imaging as a diagnostic tool for plant stress. Trends Plant Sci 2:316-320.

Lu X, Kruatrachue M, Pokethitiyook P, Homyok K (2004). Removal of cadmium and zinc by water hyacinth, Eichhornia crassipes. Science Asia 30:93-103.

Maczulak A (2009). Cleaning up the environment: Hazardous waste technology, Facts On File, Inc., NY.

Mihucz V, Csog A, Fodor F, Tatar E, Szoboszlai N, SilaghiDumitrescu L, Zaray Gy (2012). Impact of two iron (III) chelators on the iron, cadmium, lead and nickel accumulation in poplar grown under heavy metal stress in hydroponics. J Plant Physiol 169:561-566.

Mishra VK, Tripathi BD (2008). Accumulation of chromium and zinc from aqueous solution using water hyacinth (Eichhornia crassipes). Bioresource Technol 99:7091-7097.

Mudgal V, Madaan N, and Mudgal A (2010). Heavy metals in plants: phytoremediation: Plants used to remediate heavy metal pollution. Agr Biol J N Am 1:40-46.

Naaz S, Pandey SN (2010). Effects of industrial waste water on heavy metal accumulation, growth and biochemical responses of lettuce (Lactuca sativa L.). J Environ Biol 31:273-276.

Naumann B, Eberius M, Appenroth KJ (2007). Growth rate based dose-response relationships and EC - values of ten heavy metals using the duckweed growth inhibitions test (ISO 20079) with Lemna minor L. clone St. J Plant Physiol
164:1656-1664.

Peng K, Luo C, Lou L, Li X, Shen Z (2008). Bioaccumulation of heavy metals by the aquatic plants Potamogeton pectinatus L. and Potamogeton malaianus Miq. and their potential use for contamination indicators in wastewater treatment. Sci Total Environ 392:22-29.

Rahman MA, Hasegawa H (2011). Aquatic arsenic: Phytoremediation using floating macrophytes. Chemosphere 83:633-646.

Romanian Government (2002). Government decision $188 / 28 / 02 / 2002$, concerning the approval of norms of waste water disposal in the environment. Retrieved from http://www.epurare.euriteh.ro/legislatie/NTPA.2002.pdf.

Singh A, Kumar CS, Agarwal A (2012). Physiological study of combined heavy metal stress on Hydrilla verticillata (1.f.) Royle. Int J Environ Sci 2(4):2234-2242.

Singh J, Kalamdhad AS (2013). Assessment of bioavailability and leachability of heavy metals during rotary drum composting of green waste (Water hyacinth). Ecol Eng 52:59-69.

Skinner K, Wright N, Porter-Goff E (2007). Mercury uptake and accumulation by four species of aquatic plants. Environ Pollut 145:234-237.

Vesely T, Tlustos P, Száková J (2011). The use of water lettuce (Pistia stratiotes L.) for rhizofiltration of a highly polluted solution by cadmium and lead. Int $\mathrm{J}$ Phytoremediat 13(9):859-72.

Zhu YL, Zayed AM, Qian JH, Souza M, Terry N (1999). Phytoaccumulation of trace elements by wetland plants: II. Water hyacinth. J Environ Qual 28:339-344.

Yeşim K, Davut B, Izzet K, Ali Z, Hasan G (2003). Bioaccumulation of nickel by aquatic macrophyta Lemna minor (Duckweed). J Agr Biol 3:281-283. 